\title{
Featured Commentary: Special Issue on the Middle East North Africa Region
}

\author{
Melodena Stephens Balakrishnan, University of Wollongong in Dubai, United Arab Emirates
}

The MENA REgION IS FILLED with contrasts. Though some of the oldest civilizations exist here, there are still geographical boundaries that are undefined, such as Palestine (home to 10 million people). The Arab Spring, which began at the end of 2010, has led to mass migration of over 1 million people from Tunisia, Libya, and Syria that surged to neighbouring countries in Africa, Asia, and Europe, creating a humanitarian crisis. Relevance of aid, NGOs and their internationalization and reach, public diplomacy, and emergence of social entrepreneurship are all possible topics that should gain more importance for the IB community. Migration and impact on culture are other areas of study.

Though some countries in the MENA region have among the world's highest per capita GDPs, 19 percent of the regional population lives on less than US\$2 a day (Kouame, 2009). MENA has the highest rate of unemployed youth aged 15-24 (over 25 percent), though it also has one of the youngest populations in the world (45 percent under the age of 15). While some countries like the UAE are empowering their women, MENA — with a total population of 315 million -also has a female unemployment rate of 32 percent (World Bank, 2007; see Kabbani \& Kothari, 2005, for details; Population Reference Bureau, 2001). The oil-rich Gulf Cooperation Council (GCC) labour markets are getting saturated, and the quandary is that these governments cannot afford to employ many more citizens, but by 2025 there will be another 160 million adults of working age waiting to be employed — this will impact expatriation and nationalization policies (Rodenbeck, 2000; Williamson \& Yousef, 2002). IB can focus on nationalization and implication of knowledge flows, talent management in the face of crisis and mobility, gender empowerment, entrepreneurship facilitation, culture dilution and preservation, and easternization versus westernization trends.

MENA has resource-rich countries, e.g., OPEC members, but the fact remains that in the Gulf up to 10 percent of all oil export revenue is spent on food (Hakimian, 2003). Water scarcity in MENA, one of the most arid regions in the world, will increase by another 50 percent by 2050 as population increases (World Bank 2011); 20 percent of the world's armed conflicts occur in the MENA region (Ibrahim, 2000). The benefits of aid continue to be questioned as seen by the economic and political crisis facing Egypt. More studies are needed on the ripple effects of this crisis and the value of a consumption economy. Sustainability, urbanization, health management, education, and supply chain management will continue to evolve as key topics for the future.
MENA Sovereign Wealth Funds (SWFs), which accounted for 57 percent of all funds and 75 percent of the aggregate assets of SWFs (Hedge Fund Marketing, 2010), are now being reinvested in MENA and more often used as hedge funds to manage risk. The re-emergence of the SouthSouth and South-East trade routes will impact the global economy. The reinvestment in infrastructure is changing the trade routes of the world! IB policy makers can look at the role of SWFs and their impact on policy, and the role of tourism and bidding for events like the FIFA World Cup, World Expo, and Olympics on the economy and nation image of countries in the region. As the retail industry evolves and more emerging market brands explode into the global market space, research can look at globalisation from the emerging market point of view. With a common GCC currency being considered, lessons from the EU may be transferable.

In short, there is a need to redefine the boundaries of IB from an emerging market context and look at new topics as globalisation, not internationalisation, will drive the world! This special issue highlights some important research areas that need to be addressed, and we hope the momentum will continue, especially as research on this region accounts for less than 1 percent of all globally published research in business, management, and accounting (SCImagojr.com, 2011; Robertson et al., 2001).

\section{References}

Hakimian, H. 2003. Water scarcity and food imports: An empirical investigation of the 'virtual water' hypothesis in the MENA region. Review of Middle East Economics and Finance, 1(1): 71-85.

Hedge Fund Marketing. 2010. Sovereign wealth funds investing in hedge funds. http://www.hedgefundmarketing.org/sovereign-wealthfunds-investing-in-hedge-funds/.

Ibrahim, S. E. 2000. Arab social-science research in the 1990s and beyond: Issues, trends, and priorities. In E. Rached, \& D. Craissati (Eds), Research for development in the Middle East and North Africa. Ottawa: International Development Research Centre. http://web.idrc.ca/openebooks/310-0/.

Kabbani, N., \& Kothari, E. 2005. Youth employment in the MENA region: A situational assessment. SP Discussion Paper, http://siteresources. 
worldbank.org/SOCIALPROTECTION/Resources/SP-Discussionpapers/Labor-Market-DP/0534web.pdf.

Kouame, A. 2009. Q\&A on global financial crisis. World Bank. http://web. worldbank.org/WBSITE/EXTERNAL/COUNTRIES/MENAEXT/0,_c ontentMDK:22153569 pagePK:146736 piPK:146830 theSite PK:256299,00.html.

Population Reference Bureau. (2001), Population trends and challenges in the Middle East and North Africa, available: http://www.prb. org/pdf/PoptrendsMiddleEast.pdf

Robertson, C., Al-Habib, M., Al-Khatib, J., \& Lanoue, D. 2011. Beliefs about work in the Middle East and the convergence and divergence of values. Journal of World Business, 36(3): 223-244.

Rodenbeck, M. 2000. An emerging agenda for development in the Middle East and North Africa. In E. Rached \& D. Craissati, (Eds), Research for development in the Middle East and North Africa. Ottawa: International Development Research Centre. http:// web.idrc.ca/openebooks/310-0/.

SCImagojr.com. 2011. SJR-SCImago journal \& country rank. http//www. scimagojr.com.

Williamson, J., \& Yousef, T. 2002. Demographic transitions and economic performance in the Middle East and North Africa. In I. Sirageldin (Ed.), Human capital: Population economics in the Middle East: 16-36. London: I.B.Tauris \& Co. Ltd.
World Bank. 2007. The road not travelled: Educational reform in the Middle East and North Africa. http://siteresources.worldbank.org/ INTMENA/Resources/EDU_01-Chap01-Education.pdf.

World Bank. 2011. Dealing with water scarcity in MENA. http://web. worldbank.org/WBSITE/EXTERNAL/COUNTRIES/MENAEXT/0 „CO ntentMDK:21872903 menuPK:247603 pagePK:2865106 piPK :2865128 theSitePK:256299,00.html.

Melodena Balakrishnan has over 16 years of corporate and academic experience. She has a multicultural background having lived in India, USA, Taiwan and now UAE. Her corporate experience was in marketing, product development, and joint venture negotiations. In academia, she has been involved in strategic planning, accreditations, course development and industry outreach. Her areas of research are place branding, social entrepreneurship, crisis management, and loyalty studies. She has published and also won several competitive research grants and recognitions in these areas. As fonder the Academy of International Business - MENA chapter (AIBMENA), she has contributed to the visibility of the region in education and research by the organization of 3 international conferences which brought together over 200 participants, produced 4 books, 35 teaching cases and 2 special academic journal issues. AIBMENA has been recognized by the Dubai Conventions Bureau as Brand Ambassadors for Dubai. 